\title{
Source Data Verification Document
}

National Cancer Institute

\section{Source}

National Cancer Institute. Source Data Verification Document. NCI Thesaurus. Code C125433.

A document describing source data and associated verification activity. 